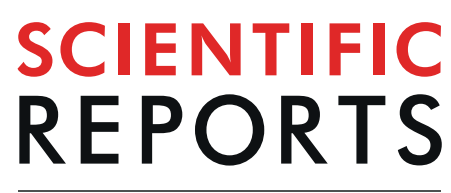

natureresearch

Check for updates

\title{
Improved Non-Grignard Electrolyte Based on Magnesium Borate Trichloride for Rechargeable Magnesium Batteries
}

\author{
Kazuhiko Sato ${ }^{1}$, Goro Mori ${ }^{1}$, Takahiro Kiyosu ${ }^{1}$, Toyonari Yaji ${ }^{2}$, Koji Nakanishi ${ }^{2,4}$, \\ Toshiaki Ohta $^{2}$, Kuniaki Okamoto ${ }^{1}$ \& Yuki Orikasa ${ }^{3 凶}$
}

The high anodic stability of electrolytes for rechargeable magnesium batteries enables the use of new positive electrodes, which can contribute to an increase in energy density. In this study, novel $\mathrm{Ph}_{3} \mathrm{COMgCl}$, $\mathrm{Ph}_{3} \mathrm{SiOMgCl}$-, and $\mathrm{B}(\mathrm{OMgCl})_{3}$-based electrolytes were prepared with $\mathrm{AlCl}_{3}$ in triglyme. The $\mathrm{Ph}_{3} \mathrm{COMgCl}$-based electrolyte showed anodic stability over $3.0 \mathrm{~V}$ vs. Mg but was chemically unstable, whereas the $\mathrm{Ph}_{3} \mathrm{SiOMgCl}$-based electrolyte was chemically stable but featured lower anodic stability than the $\mathrm{Ph}_{3} \mathrm{COMgCl}$-based electrolyte. Advantageously, the $\mathrm{B}(\mathrm{OMgCl})_{3}$-based electrolyte showed both anodic stability over $3.0 \mathrm{~V}$ vs. $\mathrm{Mg}$ (possibly due to the Lewis acidic nature of $\mathrm{B}$ in $\mathrm{B}(\mathrm{OMgCl})_{3}$ ) and chemical stability (possibly due to the hard acid character of $\left.\mathrm{B}(\mathrm{OMgCl})_{3}\right) . \mathrm{B}(\mathrm{OMgCl})_{3}$, which was prepared by reacting boric acid with a Grignard reagent, was characterized by nuclear magnetic resonance (NMR) spectroscopy, Fourier-transform infrared spectroscopy (FTIR), and X-ray absorption spectroscopy $(X A S)$. The above analyses showed that $\mathrm{B}(\mathrm{OMgCl})_{3}$ has a complex structure featuring coordinated tetrahydrofuran molecules. ${ }^{27} \mathrm{AI}$ NMR spectroscopy and $\mathrm{Al} K$-edge XAS showed that when $\mathrm{B}(\mathrm{OMgCl})_{3}$ was present in the electrolyte, $\mathrm{AlCl}_{3}$ and $\mathrm{AlCl}_{2}{ }^{+}$species were converted to $\mathrm{AlCl}_{4}{ }^{-}$. $\mathrm{Mg} \mathrm{K}$-edge XAS showed that the $\mathrm{Mg}$ species in $\mathrm{B}(\mathrm{OMgCl})_{3}$-based electrolytes are electrochemically positive. As a rechargeable magnesium battery, the full cell using the $\mathrm{B}(\mathrm{OMgCl})_{3}$-based electrolyte and $\mathrm{Mo}_{6} \mathrm{~S}_{8}$ Chevrel phase cathode showed stable charge-discharge cycles. Thus, $\mathrm{B}(\mathrm{OMgCl})_{3}$-based electrolytes, the anodic stability of which can be increased to $3 \mathrm{~V}$ by the use of appropriate battery materials, are well suited for the development of practical Mg battery cathodes.

Rechargeable magnesium batteries are promising alternatives to lithium-ion batteries, featuring high theoretical volumetric capacity $\left(3832 \mathrm{mAh} / \mathrm{cm}^{3}\right)$, high safety derived from the nondendritic behavior of deposited magnesium, and the high abundance of magnesium metal compared with that of lithium ${ }^{1}$. However, the advantages of magnesium batteries are only possible if appropriate electrolytes and cathodes are used with magnesium metal. Although various electrolytes have been developed for magnesium batteries by several pioneering researchers, they require further improvement for practical application ${ }^{2}$.

Early studies have shown that plating/stripping of magnesium does not occur in the electrolytes of simple magnesium salts, such as $\mathrm{Mg}\left(\mathrm{ClO}_{4}\right)_{2}$, in conventional organic solvents owing to the passivating surface/blocking layer of magnesium ${ }^{2,3}$. Aurbach et al. reported a prototype magnesium battery comprising $\mathrm{Mg}$ metal anodes and a Chevrel phase cathode ${ }^{4}$. The "dichloro complex" or "all-phenyl complex" electrolyte, which is a complex solution composed of organomagnesium compounds or organomagnesium halide with a Lewis acid such as $\mathrm{AlCl}_{3}$, was used for their prototype batteries ${ }^{4-7}$. Non-Grignard magnesium-based electrolytes, such as amide- ${ }^{8,9}$, phenolate- ${ }^{10,11}$, and alkoxide-based ${ }^{12-15}$ ones, have also been developed to be used in combination with active materials such as sulfur and to decrease sensitivity to air/moisture.

${ }^{1}$ FUJIFILM Wako Pure Chemical Corporation, 1633 Matoba, Kawagoe, Saitama, 350-1101, Japan. ${ }^{2}$ SR Center, Ritsumeikan University, 1-1-1 Nojihigashi, Kusatsu, Shiga, 525-8577, Japan. ${ }^{3}$ Department of Applied Chemistry, College of Life Sciences, Ritsumeikan University, 1-1-1 Nojihigashi, Kusatsu, Shiga, 525-8577, Japan. ${ }^{4}$ Present address: Laboratory of Advanced Science and Technology for Industry, University of Hyogo, 3-1-2 Koto, Kamigori-

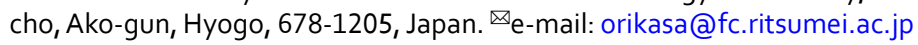


<smiles>O=C(c1ccccc1)c1ccccc1</smiles><smiles>CCCCCCCOB(OC)OC</smiles>

Figure 1. Schematic synthetic routes of various magnesium salts used in this study.

For example, Kim et al. developed $\left[\mathrm{Mg}_{2}(\mu-\mathrm{Cl})_{3} \cdot 6 \mathrm{THF}\right]\left[\mathrm{HMDSAlCl}_{3}\right](\mathrm{THF}=$ tetrahydrofuran, $\mathrm{HMDS}=$ hexamethyldisilazane) and used it in a $\mathrm{Mg} / \mathrm{S}$ battery ${ }^{9}$. Doe et al. reported a magnesium aluminum chloride complex (MACC) and showed that this electrolyte, comprising fully inorganic salts, can be used in a magnesium battery ${ }^{16,17}$. In recent years, it has also been reported that even an electrolyte without a Lewis acid causes magnesium plating/stripping. For example, $\mathrm{Mg}(\mathrm{TFSI})_{2} /$ triglyme $(\mathrm{TFSI}=$ bistriflimide) showed high electrochemical stability toward oxidation and can cause reversible magnesium plating/stripping ${ }^{18-20}$. A carborane-based electrolyte without a Lewis acid was also reported to exhibit high Coulombic efficiency and high anodic stability for SUS and Al electrodes ${ }^{21-24}$.

Magnesium is easily corroded by $\mathrm{AlCl}_{3}$ solution in thionyl chloride, although this corrosion can be suppressed by a solution of $\mathrm{Mg}\left(\mathrm{AlCl}_{4}\right)_{2}$ in thionyl chloride ${ }^{25}$. The Coulombic efficiency of magnesium plating/stripping can be improved by conditioning of the MACC electrolyte in $\mathrm{THF}^{26,27}$. Moreover, magnesium plating/stripping occurs even in the monoglyme-MACC electrolyte, the Coulombic efficiency and open circuit potential (OCP) of which differ from those of the same electrolyte in $\mathrm{THF}^{17,27}$. The addition of $\mathrm{MgCl}_{2}$ to $\mathrm{Mg}(\mathrm{TFSI})_{2}$ in 1,2-dimethoxyethane significantly improved the electrochemical performance in terms of reversible magnesium deposition ${ }^{28}$. In this case, $\mathrm{PF}_{6}{ }^{-}$anions passivate the $\mathrm{Mg}$ anodes, although reversible $\mathrm{Mg}$ deposition/dissolution commence via the addition of either $\mathrm{MgCl}_{2}$ or $\mathrm{LiCl}^{29}$. However, it is not yet known which of these electrolytes affect the deposition/ dissolution of magnesium and anodic stability.

The development of magnesium batteries requires magnesium electrolytes to show high anodic stability, be safe and easy to handle, and allow reversible magnesium plating and stripping. From the viewpoint of safety, it is desirable for the magnesium electrolyte to contain species that impart low flammability, low reactivity with ambient air, and other such properties ${ }^{30}$. In addition, previous reports suggest that electrolytes containing an inorganic anion show higher anodic stability than those containing alkyl or alkoxide anions ${ }^{23,24,30}$. Therefore, this study examined magnesium salts with an inorganic anion, borate, as magnesium electrolytes. Three novel magnesium salts, $\mathrm{Ph}_{3} \mathrm{COMgCl}, \mathrm{Ph}_{3} \mathrm{SiOMgCl}$, and $\mathrm{B}(\mathrm{OMgCl})_{3}$, in triglyme and $\mathrm{AlCl}_{3}$ solvents were synthesized and investigated by cyclic voltammetry $(\mathrm{CV})$ and linear sweep voltammetry (LSV). In addition to electrochemical performance, chemical stability was discussed on the basis of nuclear magnetic resonance (NMR) measurements. The $\mathrm{B}(\mathrm{OMgCl})_{3}$-based electrolyte, which showed high anodic stability, was further studied by NMR spectroscopy, Fourier-transform infrared (FTIR) spectroscopy, and X-ray absorption spectroscopy (XAS).

\section{Experimental Section}

Preparation of electrolytes. The magnesium salts, $\mathrm{Ph}_{3} \mathrm{COMgCl}, \mathrm{Ph}_{3} \mathrm{SiOMgCl}$, and $\mathrm{B}(\mathrm{OMgCl})_{3}$, were prepared by reacting benzophenone, triphenylsilanol, and boric acid, respectively, with a Grignard reagent. The schematic synthetic routes of the magnesium salts used in this study are shown in Fig. 1. The detailed procedures are described in the Supporting Information. ${ }^{1} \mathrm{H}$ NMR measurements confirmed the disappearance of the $\mathrm{O}-\mathrm{H}$ proton of the reactant. Titration indicated that the ratio of magnesium and chlorine coordinated to THF was $\mathrm{Mg}: \mathrm{Cl}=1: 1$ for all magnesium salts. In an argon-filled glove box, each magnesium salt in triglyme was heated at $40^{\circ} \mathrm{C}$. Aluminum chloride was added, and the reaction mixture was stirred and then cooled to room temperature. The preparation conditions are shown in Table S1.

Characterization. $\quad{ }^{1} \mathrm{H},{ }^{11} \mathrm{~B}$, and ${ }^{27} \mathrm{Al}$ NMR spectra were recorded on a Fourier-transform NMR spectrometer $\left(400 \mathrm{MHz}, \mathrm{JMN}-\mathrm{ECS} 400\right.$, JEOL). The ${ }^{1} \mathrm{H}$ NMR spectrum of $\mathrm{B}(\mathrm{OMgCl})_{3}$ was measured using a filtered 


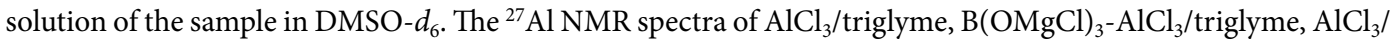
triglyme-THF, and $\mathrm{B}(\mathrm{OMgCl})_{3}-\mathrm{AlCl}_{3}$ /triglyme-THF were measured using neat samples. The ${ }^{11} \mathrm{~B} \mathrm{NMR}$ spectra of $\mathrm{B}(\mathrm{OH})_{3}$ and $\mathrm{B}(\mathrm{OMgCl})_{3}$ were measured using samples dissolved in $\mathrm{CD}_{3} \mathrm{OD} / \mathrm{CD}_{3} \mathrm{CO}_{3} \mathrm{D}$ mixed solvent $(50 / 50 \mathrm{vol} \%)$. The ${ }^{11} \mathrm{~B} \mathrm{NMR}$ spectrum of $\mathrm{B}(\mathrm{OMgCl})_{3}-\mathrm{AlCl}_{3}$ /triglyme was measured using a sample diluted with THF- $d_{8}$. Attenuated total reflection FTIR spectroscopy was performed using a Fourier-transform infrared spectrometer (Nicolet 380, Thermo Scientific). Powder X-ray diffraction (XRD) patterns were measured in the range of $2 \theta=5-50^{\circ}$ using a powder X-ray diffractometer (Miniflex 600 , Rigaku) operated at a $40 \mathrm{kV}$ voltage and $15 \mathrm{~mA}$ current using $\mathrm{Cu} \mathrm{K} \alpha$ radiation $(\lambda=1.5406 \AA)$. XAS measurements of the liquid electrolyte were performed at beamline BL-10 of the SR Center of Ritsumeikan University (Japan). A home-made measurement cell, where the electrolytes are separated from vacuum by a silicon nitride window, was used ${ }^{31}$. $\mathrm{Mg}$ and $\mathrm{Al} K$-edge XAS spectra were measured in fluorescence mode using a silicon drift detector.

Electrochemical measurements. CV and LSV were performed in an argon-filled glovebox $(<0.1$ ppm each of water and oxygen) using an electrochemical measurement system (VMP3, Bio-Logic Science Instruments). CV measurements were conducted within the potential range of -1.0 to $3.5 \mathrm{~V}$ vs. $\mathrm{Mg}$ at a scan rate of $5 \mathrm{mV} / \mathrm{s}$ using a three-electrode cell. This cell has Pt (diameter $(\varphi): 3.0 \mathrm{~mm}$, disk, BAS Co., $\operatorname{Ltd}$.), $\operatorname{Mg}(\varphi: 1.6 \mathrm{~mm}$, rod, $99.95 \%$, Nilaco Co., Ltd.), and $\mathrm{Mg}(\varphi: 1.6 \mathrm{~mm}$, rod, $99.95 \%$, Nilaco Co., Ltd.) as the working, reference, and counter electrodes, respectively, immersed in $2 \mathrm{~mL}$ of electrolyte. LSV measurements were conducted within the potential range of OCP to $3.5 \mathrm{~V}$ vs. $\mathrm{Mg}$ at a scan rate of $5 \mathrm{mV} / \mathrm{s}$ using the same cell, but with various working electrodes. These working electrodes include Pt ( $\varphi: 3.0 \mathrm{~mm}$, disk, BAS Co., Ltd.), glassy carbon (GC; $\varphi: 3.0 \mathrm{~mm}$, disk, BAS Co., Ltd.), Al (thickness: $0.1 \mathrm{~mm}$, plate, 99.999\%, Nilaco Co., Ltd.), SUS304 (thickness: $0.2 \mathrm{~mm}$, plate, Nilaco Co., Ltd.), and $\operatorname{Mo~(~} \varphi: 1.5 \mathrm{~mm}$, rod, $99.95 \%$, Nilaco Co., Ltd.).

The galvanostatic deposition of magnesium was carried out in a three-electrode cell under a current density of $1 \mathrm{~mA} / \mathrm{cm}^{2}$ applied to the Pt working electrode for $50 \mathrm{~h}$. Scanning electron microscopy (SEM) was performed using a field emission scanning electron microscope (S-4800, Hitachi, Ltd.) to observe the precipitate on the electrode. Synchrotron XRD measurements of plated magnesium were performed at beamline BL5S2 of the Aichi Synchrotron Radiation Center (Japan). A glass capillary with an outer diameter of $0.3 \mathrm{~mm}$ was filled with the sample and sealed by a resin in an argon-filled glove box. XRD data were collected using a Debye-Scherrer optical system with a two-dimensional semiconductor detector (PILATUS $100 \mathrm{~K}$, Dectris). The wavelength of the X-ray was calibrated to $\lambda=0.6995 \AA$.

Battery testing. $\mathrm{Cu}_{2} \mathrm{Mo}_{6} \mathrm{~S}_{7.8}$ was purchased from Nippon Inorganic Colour \& Chemical Co., Ltd. Hydrochloric acid and ultrapure water were purchased from FUJIFILM Wako Pure Chemical Corporation and used as received. $\mathrm{Mo}_{6} \mathrm{~S}_{8}$ Chevrel phase, the active material, was prepared by chemical leaching of $\mathrm{Cu}_{2} \mathrm{Mo}_{6} \mathrm{~S}_{7.8}$ in $\mathrm{HCl} / \mathrm{H}_{2} \mathrm{O}$ with oxygen bubbling. The electrode slurry consisted of $80 \mathrm{wt} \%$ active material, $10 \mathrm{wt} \%$ acetylene black (DENKA BLACK, Denka Co., Ltd.), and $10 \mathrm{wt} \%$ polyvinylidene fluoride (KF Polymer L\#7305, Kureha Corporation) dissolved in 1-methyl-2-pyrrolidone using a planetary ball mill. The slurry was coated onto carbon paper, which served as the current collector, and dried under vacuum at $80^{\circ} \mathrm{C}$ for $1 \mathrm{~h}$ and subsequently at $120^{\circ} \mathrm{C}$ for $5 \mathrm{~h}$. It was reported that carbon electrode is stable during magnesium charge-discharge ${ }^{32}$. The resulting sheet, along with those of AZ31 (thickness: $0.5 \mathrm{~mm}$, Izumi Metal Corporation) and glass fiber filter (GA100, Advantec), were cut into disks $16 \mathrm{~mm}$ in diameter to form the cathode, anode, and separator, respectively. The test cell was prepared by laminating the cathode, separator, and AZ31 anode on a CR2032 coin-type cell (Hohsen Corp.), which was then filled with electrolyte. Galvanostatic charge-discharge tests were carried out at a constant current of $\mathrm{C} / 50$ rate and temperature of $25^{\circ} \mathrm{C}$ using a charge/discharge unit (ABE 1024-05R1, Electrofield). The experimental conditions were based on the theoretical capacity of $\mathrm{Mo}_{6} \mathrm{~S}_{8}(128 \mathrm{mAh} / \mathrm{g})$ in the range of $0.5-1.9 \mathrm{~V} \mathrm{vs}$. $\mathrm{Mg}$ at $25^{\circ} \mathrm{C}$.

\section{Results and Discussion}

We first examined the electrochemical behaviors of the $\mathrm{Ph}_{3} \mathrm{COMgCl}-, \mathrm{Ph}_{3} \mathrm{SiOMgCl}$-, and $\mathrm{B}(\mathrm{OMgCl})_{3}$-based electrolytes. Figure 2(a) displays the cyclic voltammograms of the electrolytes, prepared by mixing a magnesium salt with $\mathrm{AlCl}_{3}$ in triglyme, at the $100^{\text {th }}$ cycle. They show reversible cathodic and anodic currents with $\mathrm{Mg}$ plating and stripping at $0 \mathrm{~V}$ vs. $\mathrm{Mg}$. The $\mathrm{B}(\mathrm{OMgCl})_{3}$-based electrolyte shows the highest reversible current density for $\mathrm{Mg}$ plating and stripping. The cyclic voltammograms of the $\mathrm{Ph}_{3} \mathrm{COMgCl}-$ and $\mathrm{Ph}_{3} \mathrm{SiOMgCl}$-based electrolytes, consisting of magnesium salts of similar structure, exhibit similar shapes with almost the same current densities. The Coulombic efficiencies are $75.7 \%, 81.5 \%$, and $64.0 \%$ for the $\mathrm{Ph}_{3} \mathrm{COMgCl}-\mathrm{Ph}_{3} \mathrm{SiOMgCl}_{-}$, and $\mathrm{B}(\mathrm{OMgCl})_{3}$-based electrolytes, respectively. The three electrolytes have different anodic stabilities. Figure 2(b) displays the linear sweep voltammograms of the electrolytes. The linear sweep voltammogram of the $\mathrm{Ph}_{3} \mathrm{COMgCl}$-based electrolyte shows anodic stability close to approximately 3.0 V vs. $\mathrm{Mg}$. On the other hand, for the $\mathrm{Ph}_{3} \mathrm{SiOMgCl}$-based electrolyte, a weak oxidation current is observed at $2.6 \mathrm{~V}$, and the anodic current increases at about $3.0 \mathrm{~V}$, which is close to the decomposition potential of the $\mathrm{Ph}_{3} \mathrm{COMgCl}$-based electrolyte. Comparison of the linear sweep voltammograms of the $\mathrm{Ph}_{3} \mathrm{COMgCl}$ - and $\mathrm{Ph}_{3} \mathrm{SiOMgCl}$-based electrolytes shows that the central element influences anodic stability. Among these electrolytes, the $\mathrm{B}(\mathrm{OMgCl})_{3}$-based electrolyte shows the highest anodic stability over $3.0 \mathrm{~V}$. The $\mathrm{B}(\mathrm{OMgCl})_{3}$-based electrolyte also exhibits long-term stability. Figure 2 (c) shows the cyclic voltammograms of the $\mathrm{Ph}_{3} \mathrm{COMgCl}$ - and $\mathrm{Ph}_{3} \mathrm{SiOMgCl}$-based electrolytes measured three weeks after the first measurement in the presence of $0.1 \mathrm{ppm}$ each of $\mathrm{H}_{2} \mathrm{O}$ and $\mathrm{O}_{2}$ in an argon-filled glove box. The $\mathrm{Ph}_{3} \mathrm{COMgCl}$-based electrolyte shows no current associated with magnesium plating/striping, while the $\mathrm{Ph}_{3} \mathrm{SiOMgCl}$-based electrolyte shows almost the same CV curve even after three weeks.

The difference in stability is related to the chemical structures of the electrolytes. Figure $2(\mathrm{~d})$ shows the ${ }^{1} \mathrm{H}$ NMR spectra of the $\mathrm{Ph}_{3} \mathrm{COMgCl}-$ and $\mathrm{Ph}_{3} \mathrm{SiOMgCl}$-based electrolytes as prepared and after three weeks. The ${ }^{1} \mathrm{H}$ 

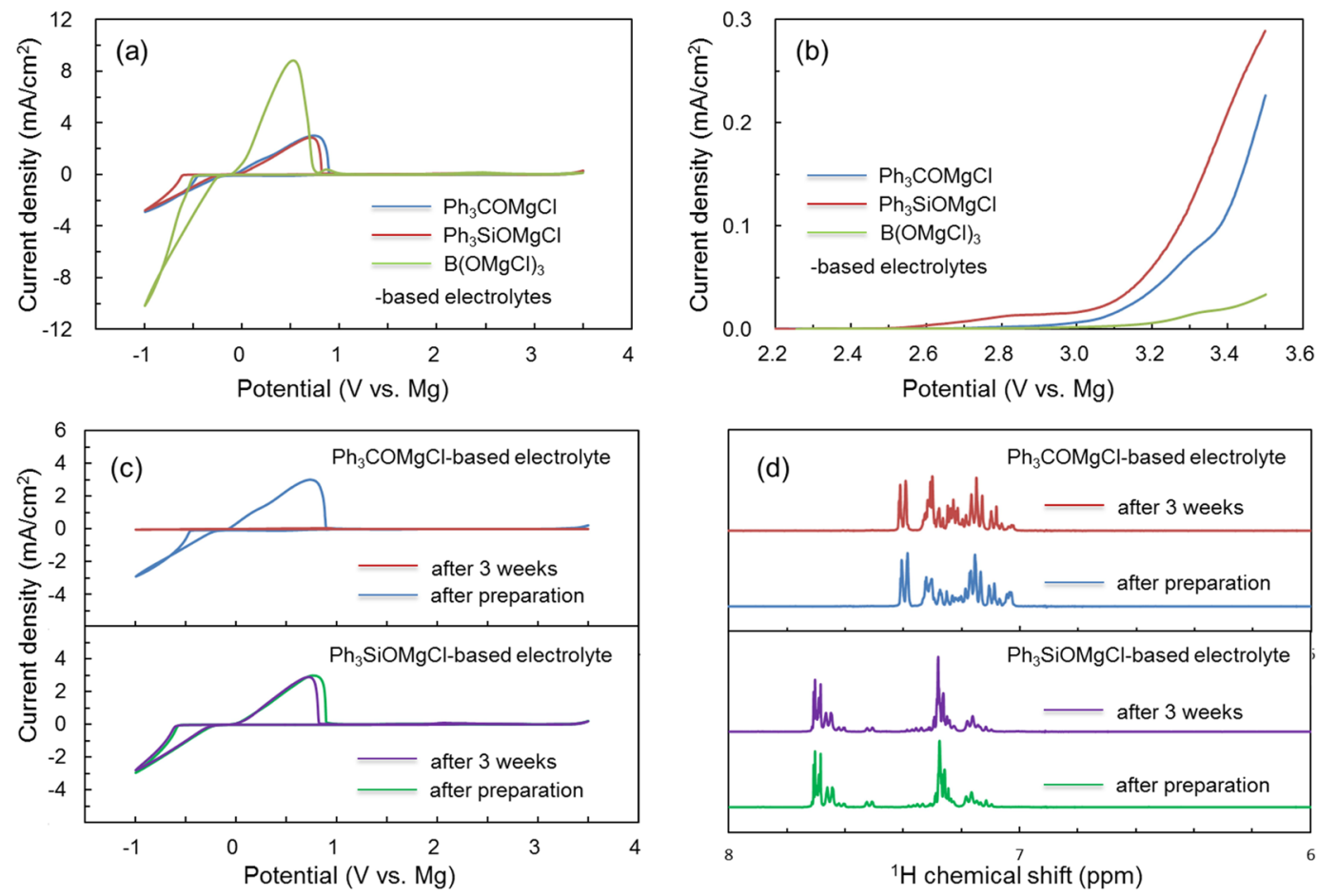

Figure 2. (a) Cyclic voltammograms of $\mathrm{Ph}_{3} \mathrm{COMgCl}$ - (blue), $\mathrm{Ph}_{3} \mathrm{SiOMgCl}$ - (red), and $\mathrm{B}(\mathrm{OMgCl})_{3}$-based (green) electrolytes at the $100^{\text {th }}$ cycle. Measurements were taken at a scan rate of $5 \mathrm{mV} / \mathrm{s}$ at $20^{\circ} \mathrm{C}$ using Pt, $\mathrm{Mg}$, and $\mathrm{Mg}$ as the working, reference, and counter electrodes, respectively, in a three-electrode cell. (b) Linear sweep voltammograms of $\mathrm{Ph}_{3} \mathrm{COMgCl}$ - (blue), $\mathrm{Ph}_{3} \mathrm{SiOMgCl}$ - (red), and $\mathrm{B}(\mathrm{OMgCl})_{3}$-based (green) electrolytes at a scan rate of $5 \mathrm{mV} / \mathrm{s}$ at $20^{\circ} \mathrm{C}$. (c) Cyclic voltammograms at the $100^{\text {th }}$ cycle measured at a scan rate of $5 \mathrm{mV} / \mathrm{s}$ at $20^{\circ} \mathrm{C}$. The blue and red curves represent the first measurement and measurement after three weeks, respectively, for the $\mathrm{Ph}_{3} \mathrm{COMgCl}$-based electrolyte. The green and purple curves represent the first measurement and measurement after three weeks, respectively, for the $\mathrm{Ph}_{3} \mathrm{SiOMgCl}$-based electrolyte. $(\mathbf{d}){ }^{1} \mathrm{H}$ NMR spectra of the $\mathrm{Ph}_{3} \mathrm{COMgCl}$-based electrolyte as prepared (blue) and three weeks after preparation (red) and $\mathrm{Ph}_{3} \mathrm{SiOMgCl}$-based electrolyte as prepared (green) and three weeks after preparation (purple).

NMR spectrum of the $\mathrm{Ph}_{3} \mathrm{COMgCl}$-based electrolyte from 7.20 to $7.35 \mathrm{ppm}$ changes between after preparation (blue) and after three weeks (red), which suggests the structural change of the $\mathrm{Ph}_{3} \mathrm{CO}^{-}$anion during preservation in the glove box. This chemical instability is hypothesized to be the cause of the change in the cyclic voltammogram of the $\mathrm{Ph}_{3} \mathrm{COMgCl}$-based electrolyte in Fig. 2(c). On the other hand, the $\mathrm{Ph}_{3} \mathrm{SiOMgCl}$-based electrolyte shows almost the same ${ }^{1} \mathrm{H}$ NMR spectrum as prepared (green) and after three weeks (purple), which indicates that the initial structure of the $\mathrm{Ph}_{3} \mathrm{SiO}^{-}$anion is maintained. Although the difference between the magnesium salts used in the electrolytes is only a single element, the $\mathrm{Ph}_{3} \mathrm{SiOMgCl}$-based electrolyte shows lower anodic stability and higher chemical stability compared with the $\mathrm{Ph}_{3} \mathrm{COMgCl}$-based electrolyte. The shape of the $\mathrm{CV}$ curve of the $\mathrm{B}(\mathrm{OMgCl})_{3}$-based electrolyte is nearly the same even after three weeks, which suggests the chemical stability of the $\mathrm{BO}_{3}{ }^{3-}$ anion structure (Figure $\mathrm{S} 1$ in the Supporting Information). Chemical stability may be related to the strengths of the $\mathrm{Si}-\mathrm{O}, \mathrm{B}-\mathrm{O}$, and $\mathrm{C}-\mathrm{O}$ bonds.

Density functional theory calculations suggest that chemical stability is related to the strength of $\mathrm{C}-\mathrm{O}, \mathrm{Si}-\mathrm{O}$, and $\mathrm{B}-\mathrm{O}$ bonds of anions determined using the hard and soft acids and bases principle (Supporting Information), further implying that the $\mathrm{C}-\mathrm{O}$ bond of $\mathrm{Ph}_{3} \mathrm{COMgCl}$-based electrolytes can be weakened by $\mathrm{Ph}$ substitution (Supporting Information). Moreover, according to previous reports, the Lewis acidic character of $\mathrm{B}(\mathrm{OMgCl})_{3}$ may enhance the anodic stability of the electrolyte ${ }^{7,15,33,34}$. Interestingly, elemental differences in the structure can change electrolyte properties, such as anodic stability and chemical stability. The $\mathrm{B}(\mathrm{OMgCl})_{3}$-based electrolyte shows both excellent anodic stability and chemical stability despite its low Coulombic efficiency. Therefore, we will discuss this electrolyte in more detail.

The cyclic voltammograms of the $\mathrm{B}(\mathrm{OMgCl})_{3}$-based electrolyte in triglyme and triglyme-THF are shown in Fig. 3(a,b), respectively. Cathodic and anodic currents around $0 \mathrm{~V}$ vs. $\mathrm{Mg}$ appear repeatedly in each cycle, which suggests that magnesium metal reversibly plates and strips on $\mathrm{Pt}$ within the $\mathrm{CV}$ measurement range. The $\mathrm{B}(\mathrm{OMgCl})_{3}$-based electrolyte in triglyme shows an overpotential of approximately $570 \mathrm{mV}$ at $1.0 \mathrm{~mA} / \mathrm{cm}^{2}$. Coulombic efficiency improves from $38.2 \%$ at the first cycle to $57.6 \%$ at the $30^{\text {th }}$ cycle. However, it is $64.0 \%$ even at the $100^{\text {th }}$ cycle, which indicates that the Coulombic efficiency of the $\mathrm{B}(\mathrm{OMgCl})_{3}$-based electrolyte in triglyme is not improved by the conditioning process as previously reported ${ }^{19,20}$. As shown in Fig. 3(b), the use of a triglyme-THF mixed solvent results in improved current density, probably because THF has a lower viscosity than triglyme $e^{35,36}$. The overpotential of the $\mathrm{B}(\mathrm{OMgCl})_{3}$-based electrolyte in triglyme-THF is approximately 

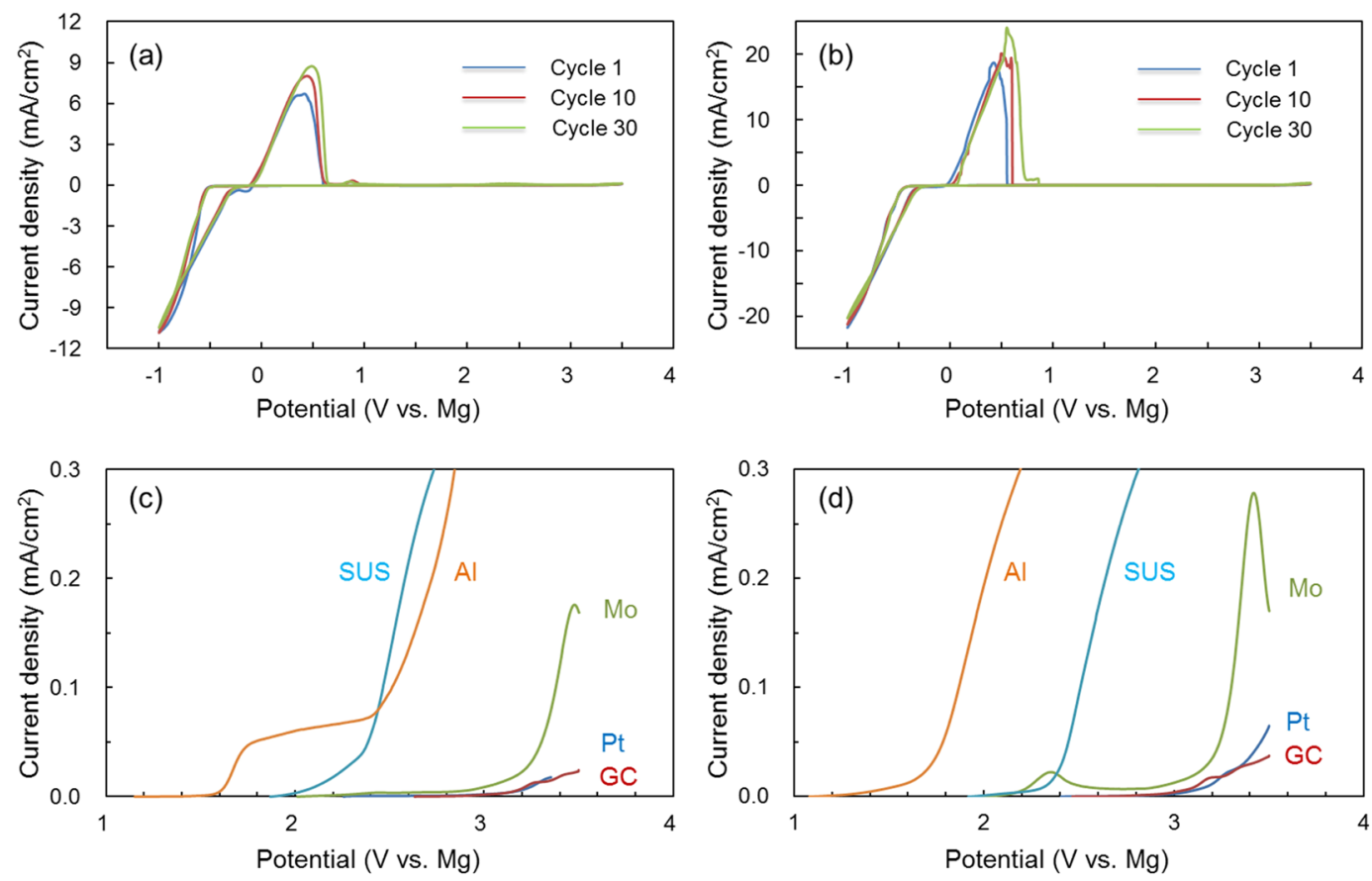

Figure 3. Cyclic voltammograms of the $\mathrm{B}(\mathrm{OMgCl})_{3}$-based electrolyte in (a) triglyme and (b) triglyme-THF measured at a scan rate of $5 \mathrm{mV} / \mathrm{s}$ at $20^{\circ} \mathrm{C}$. Linear sweep voltammograms of the $\mathrm{B}(\mathrm{OMgCl})_{3}$-based electrolyte with Pt (blue), glassy carbon (red), Mo (green), SUS (light blue), and $\mathrm{Al}$ (orange) electrodes in (c) triglyme and (d) triglyme-THF measured at a scan rate of $5 \mathrm{mV} / \mathrm{s}$.

$490 \mathrm{mV}$ at $1.0 \mathrm{~mA} / \mathrm{cm}^{2}$. The conductivity of the $\mathrm{B}(\mathrm{OMgCl})_{3}$-based electrolyte at $27^{\circ} \mathrm{C}$ improves from $2.15 \mathrm{mS} /$ $\mathrm{cm}$ without THF to $3.8 \mathrm{mS} / \mathrm{cm}$ with THF. Thus, the current density is enhanced by adding THF. The Coulombic efficiency of the $\mathrm{B}(\mathrm{OMgCl})_{3}$-based electrolyte increases from $43.4 \%$ at the first cycle to $62.8 \%$ at the $30^{\text {th }}$ cycle. The cycle dependency of Coulombic efficiency is illustrated in Figure S2 in the Supporting Information. The origin of the insufficient overvoltage and Coulombic efficiency will be discussed after the characterization of the electrolyte.

Figure 3(c,d) show the linear sweep voltammograms of the $\mathrm{B}(\mathrm{OMgCl})_{3}$-based electrolyte in triglyme and triglyme-THF, respectively. The $\mathrm{B}(\mathrm{OMgCl})_{3}$-based electrolyte in triglyme shows anodic stability over $3.0 \mathrm{~V}$ vs. Mg using Pt and GC. However, its anodic stability decreases to $1.6 \mathrm{~V}$ using $\mathrm{Al}$ and $2.0 \mathrm{~V}$ using SUS. This behavior is also observed in the $\mathrm{B}(\mathrm{OMgCl})_{3}$ /triglyme-THF electrolyte. The trend in the anodic stability of the $\mathrm{B}(\mathrm{OMgCl})_{3}$-based electrolyte is $\mathrm{Al}<\mathrm{SUS}<\mathrm{Pt}, \mathrm{GC}$ regardless of the solvent. The same trend is observed in bisamide- and dialkoxide-based electrolytes, which indicates that $\mathrm{Cl}^{-}$has an oxidatively unfavorable effect on $\mathrm{Al}$ and $\mathrm{SUS}^{8,13}$. Using $\mathrm{Mo}$, the $\mathrm{B}(\mathrm{OMgCl})_{3}$-based electrolyte in triglyme shows an anodic stability of about $3.0 \mathrm{~V}$, while the $\mathrm{B}(\mathrm{OMgCl})_{3}$-based electrolyte in triglyme-THF shows a weak decomposition current from $2.0 \mathrm{~V}$ and increased current at about $3.0 \mathrm{~V}$ vs. $\mathrm{Mg}$. Pt and $\mathrm{GC}$ can be used as current collectors with the $\mathrm{B}(\mathrm{OMgCl})_{3}$-based electrolyte up to $3.0 \mathrm{~V}$ vs. $\mathrm{Mg}$, and SUS up to about $2.0 \mathrm{~V}$ vs. $\mathrm{Mg}$. Mo can be used with the $\mathrm{B}(\mathrm{OMgCl})_{3}$-based electrolyte in triglyme up to approximately $3.0 \mathrm{~V}$ vs. $\mathrm{Mg}$.

We confirmed that the plated product is $\mathrm{Mg}$ metal without dendritic formation. SEM images of plated magnesium from the $\mathrm{B}(\mathrm{OMgCl})_{3}$-based electrolyte in triglyme and triglyme-THF on Pt are shown in Fig. 4(a,b), respectively. The SEM images show that the magnesium from the $\mathrm{B}(\mathrm{OMgCl})_{3}$-based electrolytes in different solvents appears to co-exist with a few grain-like particles and flat surface. The products from either electrolyte do not show dendritic morphology. The magnesium deposited from both electrolytes does not have a well-defined crystal morphology, and its grain size appears to be smaller than $2 \mu \mathrm{m}$. The crystalline edges are not clear, probably caused by the long-term reduction during sample preparation. Density functional theory calculations revealed the cathodic instability of $\mathrm{Mg}$-coordinated glyme electrolytes ${ }^{37}$. The long-term reduction causes partial decomposition of the $\mathrm{B}(\mathrm{OMgCl})_{3}$-based electrolyte, resulting in the mossy structure observed in the SEM images. Synchrotron radiation XRD measurement confirmed that the precipitate is magnesium, as shown in Fig. 4(c). Both XRD patterns for the $\mathrm{B}(\mathrm{OMgCl})_{3}$-based electrolytes with/without THF show the peaks at the same position as those of the reference for $\mathrm{Mg}$, although the scattering pattern in the (002) plane at $2 \theta=15.4^{\circ}$ is slightly smaller. Previous reports suggest that a small reflection of the (002) plane for magnesium represents a small grain $\operatorname{size}^{29,38-40}$. Plated magnesium can become polycrystalline depending on the precipitation conditions, and the change appears in the (002) plane, which is the close-packed surface of the magnesium crystal ${ }^{39}$. The small grain size of plated magnesium from the $\mathrm{B}(\mathrm{OMgCl})_{3}$-based electrolytes is considered to be caused by the influence of such polycrystallization.

Although Mg plating and stripping with high anodic stability is observed, the Coulombic efficiency is approximately $60 \%$ at the $100^{\text {th }}$ cycle. We will discuss the possibility of this Coulombic efficiency considering 
(a)

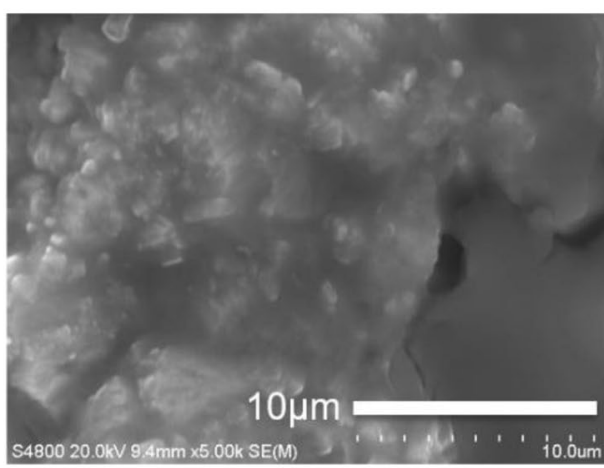

(b)

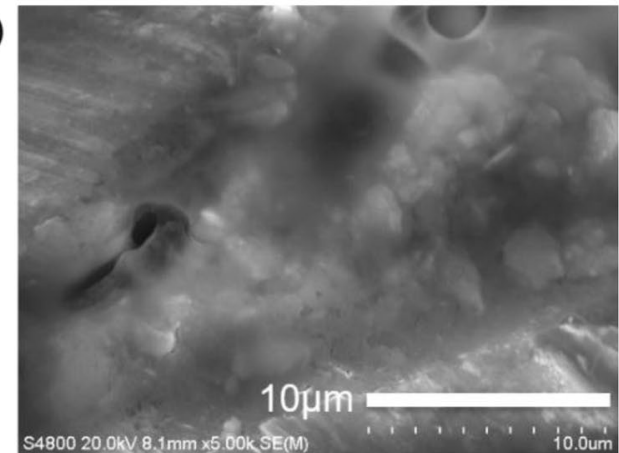

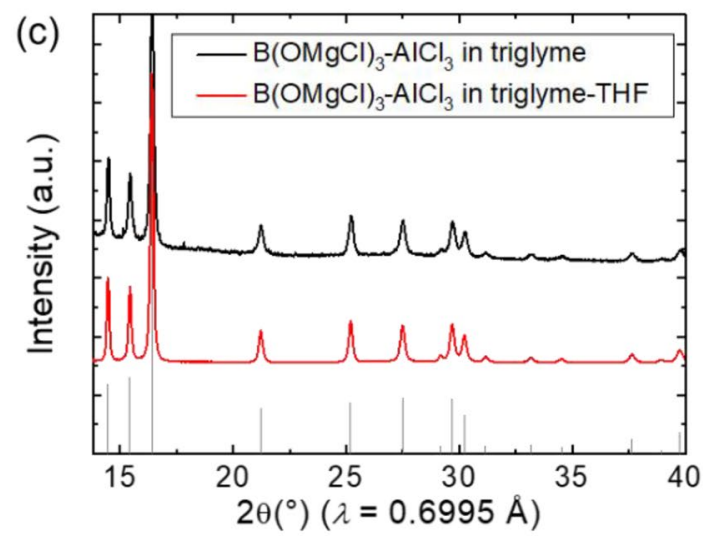

Figure 4. SEM images of electrodeposited $\mathrm{Mg}$ from the $\mathrm{B}(\mathrm{OMgCl})_{3}$-based electrolyte in (a) triglyme and (b) triglyme-THF on a Pt electrode. (c) Synchrotron radiation XRD patterns of electrodeposited $\mathrm{Mg}$ from the $\mathrm{B}(\mathrm{OMgCl})_{3}$-based electrolyte in triglyme (black) and triglyme- $\mathrm{THF}$ (red) compared with that of reference $\mathrm{Mg}$ (gray).

the chemical structure of the $\mathrm{B}(\mathrm{OMgCl})_{3}$-based electrolytes inferred from FTIR, NMR, and X-ray absorption fine structure (XAFS) analyses. First, we rule out the possibility of residual $\mathrm{B}(\mathrm{OH})_{3}$. FTIR measurements of the $\mathrm{B}(\mathrm{OMgCl})_{3}$ product, $\mathrm{B}(\mathrm{OH})_{3}$ reactant, and THF solvent are shown in Fig. 5(a). While the absorption related to the $\gamma_{\mathrm{O}-\mathrm{H}}$ peak of $\mathrm{B}(\mathrm{OH})_{3}(\mathrm{red})$ at about $3200 \mathrm{~cm}^{-1}$ is not observed in the spectrum of $\mathrm{B}(\mathrm{OMgCl})_{3}$, absorptions with similar shape to those of THF (green) are observed in the range of $800-1100$ and $2800-3100 \mathrm{~cm}^{-1}$. The absorption at the latter is attributed to the $\nu_{\mathrm{C}-\mathrm{H}}$ of THF and those at 877 and $1026 \mathrm{~cm}^{-1}$ are attributed to the red-shifts of $\delta_{\mathrm{C}-\mathrm{C}-\mathrm{O}}\left(905 \mathrm{~cm}^{-1}\right)$ and $\gamma_{\mathrm{C}-\mathrm{O}}\left(1065 \mathrm{~cm}^{-1}\right)$ of THF, respectively ${ }^{41,42}$. These results imply the consumption of the $\mathrm{B}(\mathrm{OH})_{3}$ reactant, which is also supported by the absence of the associated peak in the XRD pattern of the synthesized $\mathrm{B}(\mathrm{OMgCl})_{3}$ shown in Fig. $5(\mathrm{~b})$. The absence of diffraction peaks suggests that the $\mathrm{B}(\mathrm{OMgCl})_{3}$ salt has a disordered molecular arrangement and no other magnesium salt such as $\mathrm{MgCl}_{2}$ is formed. The ${ }^{1} \mathrm{H}$ NMR spectra of $\mathrm{B}(\mathrm{OMgCl})_{3}$ and $\mathrm{B}(\mathrm{OH})_{3}$ dissolved in $\mathrm{DMSO}-d_{6}$ are shown in Fig. $5(\mathrm{c})$. The broad $\mathrm{O}-\mathrm{H}$ peak at $5.8 \mathrm{ppm}$ detected in $\mathrm{B}(\mathrm{OH})_{3}$ is not observed in $\mathrm{B}(\mathrm{OMgCl})_{3}$, which further proves that $\mathrm{B}(\mathrm{OH})_{3}$ is completely consumed in the reaction, as implied by the FTIR and XRD results. The new peaks observed at 1.76 and 3.59 ppm indicate that THF remains in the synthesized magnesium salt ${ }^{43}$, which is also consistent with the FTIR results showing the coordination of THF to the magnesium salt.

Although the $\mathrm{B}(\mathrm{OH})_{3}$ itself no longer remains, the presence of the $\mathrm{BO}_{3}{ }^{3-}$ unit is confirmed by the ${ }^{11} \mathrm{~B} \mathrm{NMR}$ spectra of $\mathrm{B}(\mathrm{OH})_{3}$ and $\mathrm{B}(\mathrm{OMgCl})_{3}$, which were both dissolved in $\mathrm{CD}_{3} \mathrm{OD} / \mathrm{CD}_{3} \mathrm{CO}_{2} \mathrm{D}$ (50/50 vol\%) (Fig. 5(d)). The main peak in the ${ }^{11} \mathrm{~B}$ NMR spectrum of $\mathrm{B}(\mathrm{OMgCl})_{3}$ is located at around $19 \mathrm{ppm}$, which is almost the same as that of $\mathrm{B}(\mathrm{OH})_{3}{ }^{44}$. The presence of this peak indicates that the $\mathrm{BO}_{3}{ }^{3-}$ unit remains in the structure of $\mathrm{B}(\mathrm{OMgCl})_{3}$. The origin of the other peaks (around 2 and $32.4 \mathrm{ppm}$ ) are unknown at present. However, these peaks are unrelated to the solvents used for the measurement $\left(\mathrm{CD}_{3} \mathrm{OD}\right.$ and $\left.\mathrm{CD}_{3} \mathrm{CO}_{2} \mathrm{D}\right)$ because they are also detected in the $\mathrm{B}(\mathrm{OMgCl})_{3}$-based electrolytes described later.

$\mathrm{B}(\mathrm{OH})_{3}$ is not detected in the FTIR, XRD, and ${ }^{1} \mathrm{H}$ NMR measurements, and the $\mathrm{BO}_{3}{ }^{3-}$ unit remains in the $\mathrm{B}(\mathrm{OMgCl})_{3}$ salt according to the ${ }^{11} \mathrm{~B}$ NMR measurement. Moreover, the molar ratio of $\mathrm{B}(\mathrm{OMgCl})_{3}$, measured by inductively coupled plasma-atomic emission spectroscopy and $\mathrm{Cl}$ titration, is $\mathrm{B}: \mathrm{Mg}: \mathrm{Cl}=1: 3: 3$. These results indicate that the Grignard reagent mainly reacts with $\mathrm{B}(\mathrm{OH})_{3}$ as a Brønsted acid to form $\mathrm{B}(\mathrm{OMgCl})_{3} . \mathrm{B}(\mathrm{OMgCl})_{3}$ does not show the ordered arrangement and disproportionated structures observed in the XRD measurement. In addition, the FTIR and ${ }^{1} \mathrm{H}$ NMR spectra suggest that THF is coordinated to $\mathrm{B}(\mathrm{OMgCl})_{3}$. Based on these results, the synthesized $\mathrm{B}(\mathrm{OMgCl})_{3}$ salt has the structure shown in Fig. 6(a), in which THF is coordinated to $\mathrm{B}(\mathrm{OMgCl})_{3}$, and a more complicated structure with a disordered network (Fig. 6(b)). 

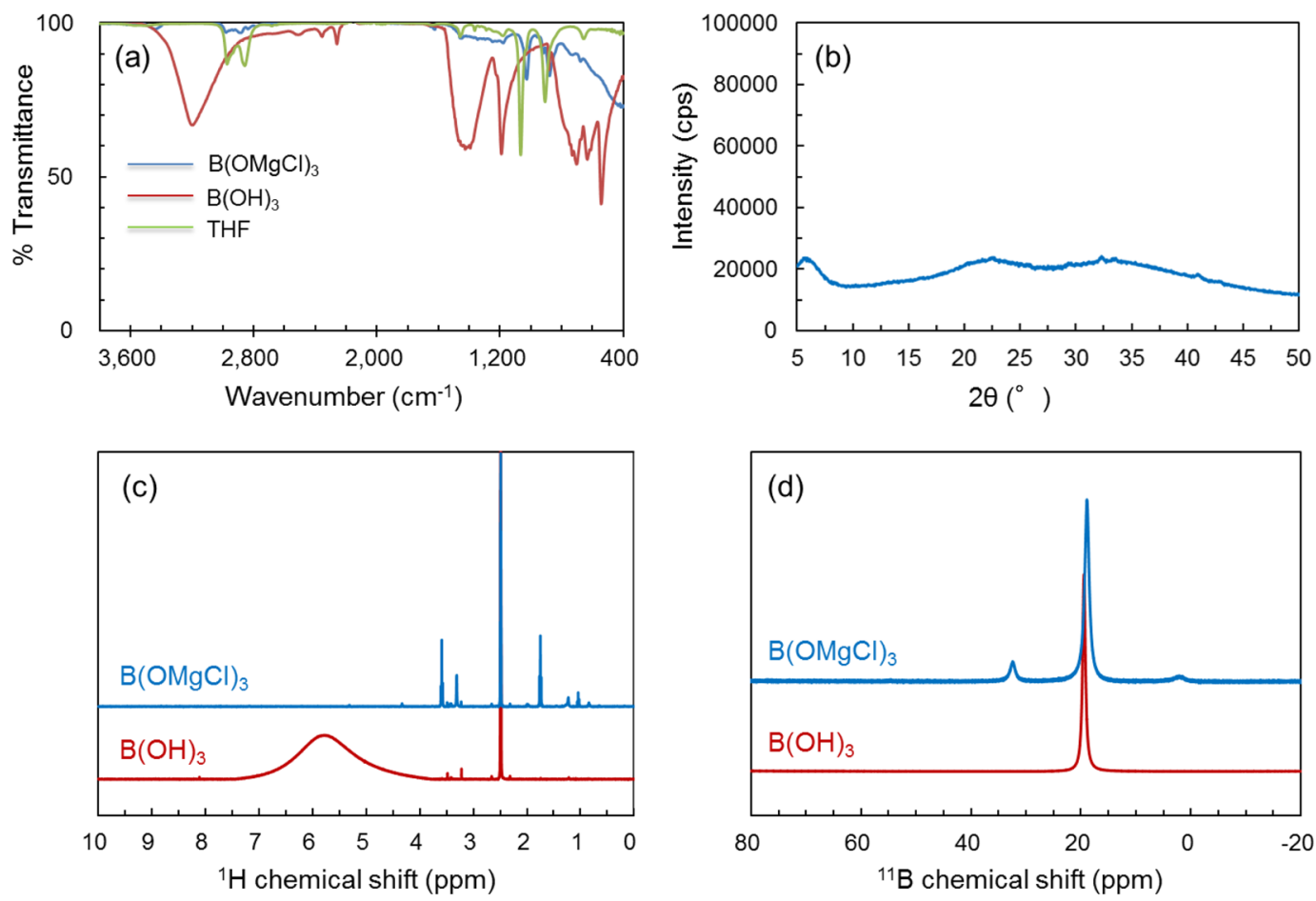

Figure 5. (a) Comparison of the FTIR transmittance spectra of $\mathrm{B}(\mathrm{OH})_{3}$ (red), $\mathrm{B}(\mathrm{OMgCl})_{3}$ (blue), and THF (green) from 400 to $3800 \mathrm{~cm}^{-1}$. (b) Powder XRD pattern of $\mathrm{B}(\mathrm{OMgCl})_{3}$. (c) ${ }^{1} \mathrm{H} \mathrm{NMR} \mathrm{spectra} \mathrm{of} \mathrm{B}(\mathrm{OMgCl})_{3}$ filtrate with DMSO- $d_{6}$ (blue) and $\mathrm{B}(\mathrm{OH})_{3}$ dissolved in DMSO- $d_{6}$ (red). $(\mathbf{d}){ }^{11} \mathrm{~B}$ NMR spectra of $\mathrm{B}(\mathrm{OMgCl})_{3}$ (blue) and $\mathrm{B}(\mathrm{OH})_{3}$ (red) dissolved in $\mathrm{CD}_{3} \mathrm{OD} / \mathrm{CD}_{3} \mathrm{CO}_{2} \mathrm{D}$ (50/50 vol\%).
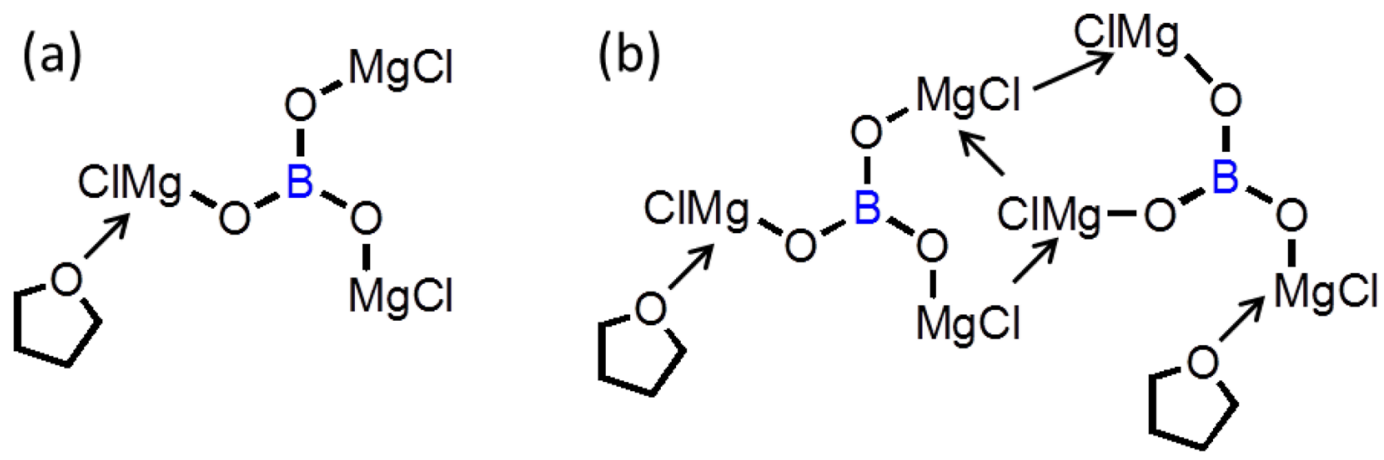

Figure 6. Plausible structures of the product from boric acid and ethylmagnesium chloride.

Subsequently, we investigated the $\mathrm{Al}$-coordinated state in $\mathrm{B}(\mathrm{OMgCl})_{3}$-based electrolytes by ${ }^{27} \mathrm{Al}$ and ${ }^{11} \mathrm{~B} \mathrm{NMR}$ spectroscopy. Figure 7 (a) shows the ${ }^{27} \mathrm{Al} \mathrm{NMR} \mathrm{spectra} \mathrm{of} \mathrm{AlCl}_{3} /$ triglyme, $\mathrm{B}(\mathrm{OMgCl})_{3}-\mathrm{AlCl}_{3} /$ triglyme, $\mathrm{AlCl}_{3} /$ triglyme-THF, and $\mathrm{B}(\mathrm{OMgCl})_{3}-\mathrm{AlCl}_{3} /$ triglyme-THF measured as neat samples. The peaks in the ${ }^{27} \mathrm{Al} \mathrm{NMR} \mathrm{spec-}$ tra of both $\mathrm{AlCl}_{3} /$ triglyme (blue) and $\mathrm{AlCl}_{3} /$ triglyme-THF (green) without $\mathrm{B}(\mathrm{OMgCl})_{3}$ are observed at approximately $106,62-68$, and $27 \mathrm{ppm}$. On the basis of literature data, the peak at $106 \mathrm{ppm}$ is assigned to the tetrahedral $\mathrm{Al}$ species including $\mathrm{AlCl}_{4}{ }^{-}$and that at $62-68 \mathrm{ppm}$ to the ether-coordinated $\mathrm{AlCl}_{3}$ species ${ }^{26,45,46}$. The peak at approximately $27 \mathrm{ppm}$ is assigned to a positive species, such as glyme-coordinated $\mathrm{AlCl}_{2}^{+46,47}$. $\mathrm{AlCl}_{3}$ ionization is expected to occur in triglyme because the dissociation of $\mathrm{AlCl}_{3}$ in glyme solvents has been observed, as shown in Eq. $(1)^{46}$ :

$$
2 \mathrm{AlCl}_{3} \leftrightarrows \mathrm{AlCl}_{2}^{+}+\mathrm{AlCl}_{4}^{-}
$$

In addition, $\mathrm{AlCl}_{3}$ is known to dissociate easily in glyme, but not in $\mathrm{THF}^{46}$. Equation (1) is deduced to shift to the left to form $\mathrm{AlCl}_{3}$ species (62-68 ppm) in triglyme-THF and to the right to form $\mathrm{AlCl}_{2}^{+}$species $(27 \mathrm{ppm})$ in triglyme solution without THF. On the other hand, approximately one peak at about $106 \mathrm{ppm}$ is observed for both $\mathrm{B}(\mathrm{OMgCl})_{3}-\mathrm{AlCl}_{3} /$ triglyme and $\mathrm{B}(\mathrm{OMgCl})_{3}-\mathrm{AlCl}_{3} /$ triglyme- $\mathrm{THF}$, which are electrolytes containing magnesium 

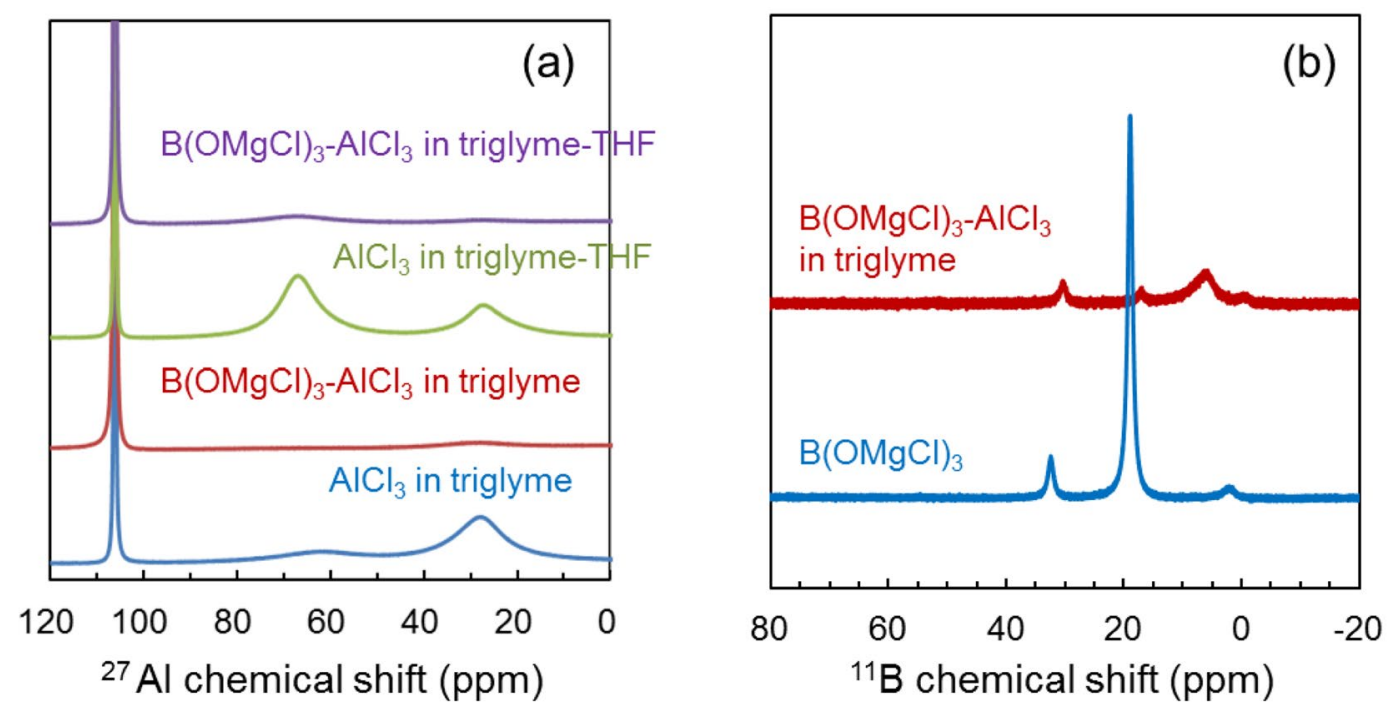

Figure 7. (a) ${ }^{27} \mathrm{Al} \mathrm{NMR} \mathrm{spectra} \mathrm{of} \mathrm{AlCl}_{3}$ in triglyme (blue), $\mathrm{B}(\mathrm{OMgCl})_{3}-\mathrm{AlCl}_{3}$ in triglyme (red), $\mathrm{AlCl}_{3}$ in triglyme-THF (50/50 vol\%) (green), and $\mathrm{B}(\mathrm{OMgCl})_{3}-\mathrm{AlCl}_{3}$ in triglyme-THF (50:50 vol\%) (purple). The concentrations of $\mathrm{AlCl}_{3}$ and $\mathrm{B}(\mathrm{OMgCl})_{3}$ in all electrolyte solutions are 1.2 and $0.2 \mathrm{M}$, respectively. $(\mathbf{b}){ }^{11} \mathrm{~B} \mathrm{NMR}$ spectra of $\mathrm{B}(\mathrm{OMgCl})_{3}$ in $\mathrm{CD}_{3} \mathrm{OD} / \mathrm{CD}_{3} \mathrm{CO}_{2} \mathrm{D}\left(50 / 50\right.$ vol\%) (blue) and $\mathrm{B}(\mathrm{OMgCl})_{3}-\mathrm{AlCl}_{3}$ in triglyme with THF$d_{8}$ (red).

salt. The reduced peaks of pentacoordinated $\mathrm{AlCl}_{3}(62-68 \mathrm{ppm})$ and $\mathrm{AlCl}_{2}{ }^{+}(27 \mathrm{ppm})$ in the $\mathrm{B}(\mathrm{OMgCl})_{3}$-based electrolyte suggest that these species are bound to the borate anion.

Figure 7(b) displays the ${ }^{11} \mathrm{~B}$ NMR spectra of a $\mathrm{B}(\mathrm{OMgCl})_{3}-\mathrm{AlCl}_{3} /$ triglyme sample diluted with THF- $d_{8}$ and $\mathrm{B}(\mathrm{OMgCl})_{3}$ sample dissolved in $\mathrm{CD}_{3} \mathrm{OD} / \mathrm{CD}_{3} \mathrm{CO}_{2} \mathrm{D}$ (50:50 vol\%). The ${ }^{11} \mathrm{~B}$ NMR spectrum of the $\mathrm{B}(\mathrm{OMgCl})_{3}-\mathrm{AlCl}_{3} /$ triglyme electrolyte shows an increase in the intensity of the broad peak at around $6 \mathrm{ppm}$ with a decrease in the intensity of the peak at approximately $19 \mathrm{ppm}$ compared with those in the ${ }^{11} \mathrm{~B}$ NMR spectrum of $\mathrm{B}(\mathrm{OMgCl})_{3}$. This suggests that the former peak is due to the $\mathrm{BO}_{3}{ }^{3-}$ species. Furthermore, these changes in the peak intensities suggest the possibility of rapid exchange of coordination of the borate anion to solvents, $\mathrm{Cl}^{-}$, and Al species, among others.

The $\mathrm{B}(\mathrm{OMgCl})_{3}$-based electrolytes were further characterized in terms of electronic and local structures. Figure 8(a) shows the $\mathrm{Mg} K$-edge $\mathrm{X}$-ray absorption near edge structure (XANES) spectra of the $\mathrm{B}(\mathrm{OMgCl})_{3}$-based electrolytes in triglyme and triglyme-THF. The two main peaks are observed at $\sim 1309$ and $\sim 1312 \mathrm{eV}$ with a shoulder at around $1315 \mathrm{eV}$. The peak at approximately $1309 \mathrm{eV}$ is attributed to either $\left[\mathrm{Mg}_{2}(\mu-\mathrm{Cl})_{2}\right]^{2+}{ }^{48}$ or $\left[\mathrm{Mg}_{2}(\mu-\mathrm{Cl})_{3}\right]^{+}$species $^{49}$. The position of the main edge at $1312-1315 \mathrm{eV}$ is related to the hexacoordinated solvated structure ${ }^{48,50}$. Figure 8 (b) shows the Fourier transform of the $\mathrm{Mg} K$-edge extended X-ray absorption fine structure (EXAFS) oscillation of the $\mathrm{B}(\mathrm{OMgCl})_{3}$-based electrolyte in triglyme. The Fourier transform for this electrolyte is closest to those for $\mathrm{Mg}\left(\mathrm{ClO}_{4}\right)_{2} / \mathrm{H}_{2} \mathrm{O}^{48}$ and $\left[\mathrm{Mg}_{2}(\mu-\mathrm{Cl})_{3} \cdot 6(\mathrm{THF})\right]^{+}$under applied voltage on the $\mathrm{Mg}$ electrode ${ }^{49}$. The peak at around $1.8 \AA$ is expected to contain information about the $\mathrm{Mg}-\mathrm{O}$ pair. On the other hand, it is unclear whether the peak at $2.6 \AA$ is the scattering peak of the $\mathrm{Mg}-\mathrm{Mg}$ pair or the peak due to the $\mathrm{Mg}-\mathrm{Cl}$ pair weakened by triglyme. However, the main edge at $1312-1315 \mathrm{eV}$ in the XANES spectrum and the large peak at $2.6 \AA$ in the EXAFS spectrum indicate that the $\mathrm{B}(\mathrm{OMgCl})_{3}$-based electrolytes include more electrochemically positive $\mathrm{Mg}$ ion than $\left[\mathrm{Mg}_{2}(\mu-\mathrm{Cl})_{3}\right]^{+}$.

Figure $8(\mathrm{c})$ represents the $\mathrm{Al} K$-edge XANES spectra of the four electrolytes, which are $\mathrm{AlCl}_{3}$ with or without $\mathrm{B}(\mathrm{OMgCl})_{3}$ dissolved in triglyme or triglyme-THF. Both $\mathrm{AlCl}_{3}$ electrolytes without $\mathrm{B}(\mathrm{OMgCl})_{3}$ in triglyme (blue) and triglyme-THF (pink) show two edges located at 1565 (with a shoulder at around $1566 \mathrm{eV}$ ) and $1568 \mathrm{eV}$. The shoulder at $1566 \mathrm{eV}$ is smaller and the peak at $1568 \mathrm{eV}$ is larger for $\mathrm{AlCl}_{3}$ /triglyme compared with those for $\mathrm{AlCl}_{3}$ /triglyme-THF. These results are consistent with those of ${ }^{27} \mathrm{Al} \mathrm{NMR}$ showing a smaller peak at $62-68$ ppm (due to $\mathrm{AlCl}_{3}$ species) and larger peak at $27 \mathrm{ppm}$ (due to $\mathrm{AlCl}_{2}{ }^{+}$species) for $\mathrm{AlCl}_{3}$ /triglyme compared with those for $\mathrm{AlCl}_{3}$ /triglyme-THF. The $\mathrm{Al} K$-edge XANES spectra of the $\mathrm{AlCl}_{3}$ electrolytes with $\mathrm{B}(\mathrm{OMgCl})_{3}$ show distinctly different absorption curves from those of the $\mathrm{AlCl}_{3}$ electrolytes without $\mathrm{B}(\mathrm{OMgCl})_{3}$ in both triglyme and triglyme-THF. The increase of the edge at $1565 \mathrm{eV}$ with the decrease of both the shoulder at around $1566 \mathrm{eV}$ and edge at $1568 \mathrm{eV}$ are consistent with the increase of the amount of $\mathrm{AlCl}_{4}{ }^{-}$and decrease of the amounts of both $\mathrm{AlCl}_{3}$ and $\mathrm{AlCl}_{2}{ }^{+}$observed in the ${ }^{27} \mathrm{Al}-\mathrm{NMR}$ measurement. The edge at $1565 \mathrm{eV}$, shoulder at around $1566 \mathrm{eV}$, and edge at $1568 \mathrm{eV}$ in the $\mathrm{Al} K$-edge XANES spectra are deduced to be related to $\mathrm{AlCl}_{4}{ }^{-}, \mathrm{AlCl}_{3}$, and $\mathrm{AlCl}_{2}{ }^{+}$, respectively.

The $\mathrm{B}(\mathrm{OMgCl})_{3}$-based electrolytes are expected to not cause the corrosive behavior. According to a previous study using $\mathrm{MgCl}_{2} / \mathrm{AlCl}_{3}$ electrolytes, the $\mathrm{AlCl}_{2}{ }^{+}$species cause $\mathrm{Mg}$ corrosion with $\mathrm{Al}$ cementation ${ }^{51}$. However, our ${ }^{27} \mathrm{Al} \mathrm{NMR}$ analysis (Fig. $7(\mathrm{a})$ ) indicated that the $\mathrm{B}(\mathrm{OMgCl})_{3}$ electrolytes do not contain $\mathrm{AlCl}_{2}{ }^{+}$. Other detected species were solvated $\left[\mathrm{Mg}_{2}(\mu-\mathrm{Cl})_{3}\right]^{+}$, glyme-solvated $\mathrm{Mg}^{2+}$, and $\mathrm{AlCl}_{4}{ }^{-}$, which reportedly do not cause corrosions.

The results above provide information on the chemical species in the $\mathrm{B}(\mathrm{OMgCl})_{3}$-based electrolytes, which can explain the origin of the low Coulombic efficiency. In the case of MACC electrolytes, $\mathrm{Mg}$ corrosion with $\mathrm{Al}$ 

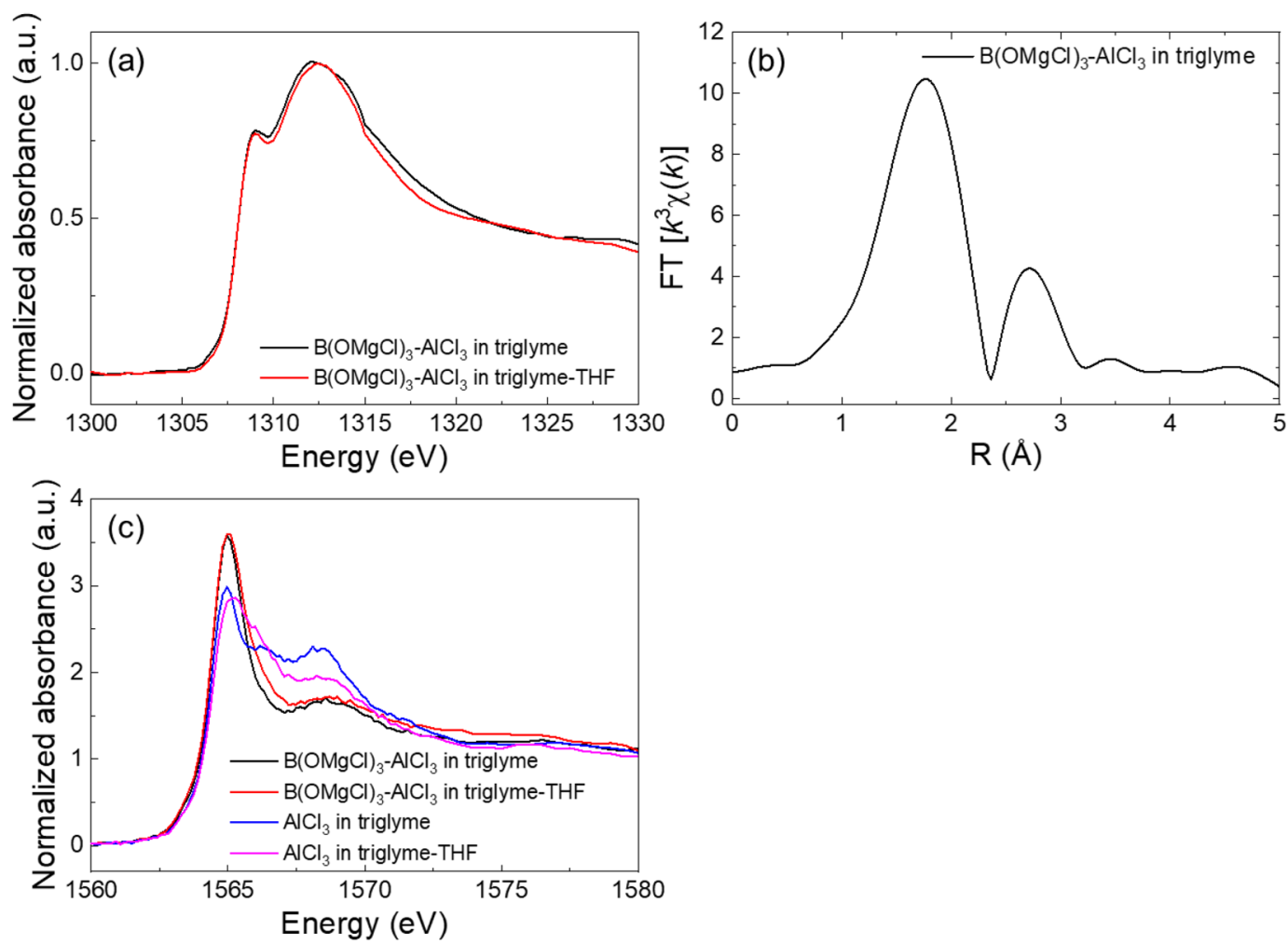

Figure 8. (a) $\mathrm{Mg} \mathrm{K}$-edge XANES spectra of $\mathrm{B}(\mathrm{OMgCl})_{3}-\mathrm{AlCl}_{3}$ in triglyme (black) and $\mathrm{B}(\mathrm{OMgCl})_{3}-\mathrm{AlCl}_{3}$ in triglyme-THF (red) and (b) Fourier transform of the EXAFS function of the former. (c) Al $K$-edge XANES spectra of $\mathrm{B}(\mathrm{OMgCl})_{3}-\mathrm{AlCl}_{3}$ in triglyme (black), $\mathrm{B}(\mathrm{OMgCl})_{3}-\mathrm{AlCl}_{3}$ in triglyme-THF (red), $\mathrm{AlCl}_{3}$ in triglyme (blue), and $\mathrm{AlCl}_{3}$ in triglyme-THF (pink).

cementation caused by $\mathrm{AlCl}_{2}{ }^{+}$reduces the Coulombic efficiency ${ }^{51}$. The Coulombic efficiency gradually improves during the $\mathrm{CV}$ cycles, which is related to the presence of $\mathrm{Al}$ species ${ }^{27}$. However, due to the absence of $\mathrm{AlCl}_{2}{ }^{+}$and no improvement in Coulombic efficiency upon $\mathrm{CV}$ cycling in the $\mathrm{B}(\mathrm{OMgCl})_{3}$-based electrolytes, we conclude that the low Coulombic efficiency observed herein is originated by a different mechanism. Energy-dispersive $\mathrm{X}$-ray spectroscopic analysis of the plated $\mathrm{Mg}$ in this study also detected the presence of $\mathrm{Al}$, which can disturb the Mg stripping. The enlarged CV profiles from Fig. 3(a) are provided as Figure S3 in the supporting information, in which the oxidation peaks are not related to $\mathrm{Mg}$ stripping but $\mathrm{Al}$ stripping. Based on the results of XAFS and $\mathrm{NMR}$, the main species in the electrolytes are solvated $\left[\mathrm{Mg}_{2}(\mu-\mathrm{Cl})_{3}\right]^{+}$, glyme-solvated $\mathrm{Mg}^{2+}$, and $\mathrm{AlCl}_{4}{ }^{-}$. The presence of $\mathrm{AlCl}_{4}{ }^{-}$potentially leads to the following chemical equilibrium ${ }^{52}$ :

$$
2 \mathrm{AlCl}_{4}^{-} \leftrightarrows \mathrm{Al}_{2} \mathrm{Cl}_{7}^{-}+\mathrm{Cl}^{-}
$$

Compared with conventional MACC electrolytes, the $\mathrm{B}(\mathrm{OMgCl})_{3}$-based electrolytes contain excess $\mathrm{AlCl}_{3}$ during preparation (Table S1), which drives the equilibrium to the right, resulting in Al plating on the electrode ${ }^{53}$ :

$$
4 \mathrm{Al}_{2} \mathrm{Cl}_{7}^{-}+3 \mathrm{e}^{-} \rightarrow \mathrm{Al}+7 \mathrm{AlCl}_{4}^{-}
$$

This trend is supported by the local structural change observed by $\mathrm{Al} K$-edge EXAFS, as shown in Figure S4. The first neighbor shell of $\mathrm{Al}$ in the $\mathrm{B}(\mathrm{OMgCl})_{3}$-based electrolytes is expanded compared with that of $\mathrm{AlCl}_{4}{ }^{-}$, which shows good agreement with the literature ${ }^{52}$. However, the ${ }^{27} \mathrm{Al} \mathrm{NMR}$ analysis of the $\mathrm{B}(\mathrm{OMgCl})_{3}$-based electrolytes does not clearly detect the $\mathrm{Al}_{2} \mathrm{Cl}_{7}{ }^{-}$species, which should be observed at $92 \mathrm{ppm}$. This result implies the low concentration of $\mathrm{Al}_{2} \mathrm{Cl}_{7}^{-}$despite the influence of $\mathrm{Al}$ plating. $\mathrm{AlCl}_{3}$ concentration must be optimized to improve Coulombic efficiency.

We have confirmed the high chemical and long-term stability of the $\mathrm{B}(\mathrm{OMgCl})_{3}$-based electrolytes and have characterized these electrolytes. Finally, the application of these electrolytes to magnesium rechargeable battery was examined. Figure $9(\mathrm{a}, \mathrm{b})$ represent the galvanostatic charge-discharge profiles of the $\mathrm{Mo}_{6} \mathrm{~S}_{8} / \mathrm{AZ} 31$ coin-type cells with $\mathrm{B}(\mathrm{OMgCl})_{3}-\mathrm{AlCl}_{3}$ /triglyme and $\mathrm{B}(\mathrm{OMgCl})_{3}-\mathrm{AlCl}_{3} /$ triglyme-THF. Both profiles show plateaus at $\sim 1.05$ and $\sim 1.20 \mathrm{~V}$ and reversible charge/discharge cycles at a capacity of approximately $80 \mathrm{mAh} / \mathrm{g}$ for 30 cycles. The profile of the cell with the $\mathrm{B}(\mathrm{OMgCl})_{3}-\mathrm{AlCl}_{3}$ /triglyme-THF electrolyte shows a slightly smaller gap between the charge-discharge plateaus compared with that of the cell with the $\mathrm{B}(\mathrm{OMgCl})_{3}-\mathrm{AlCl}_{3} /$ triglyme electrolyte. These results verify that, with $\mathrm{B}(\mathrm{OMgCl})_{3}$-based electrolytes, the charge-discharge cycles are repeated on cells with a Chevrel phase cathode and magnesium anode. This indicates that $\mathrm{Mg}^{2+}$ insertion/de-insertion into/from the Chevrel phase with $\mathrm{Mg}$ plating/stripping proceeds repeatedly. In addition, it also confirms that SUS can be used 

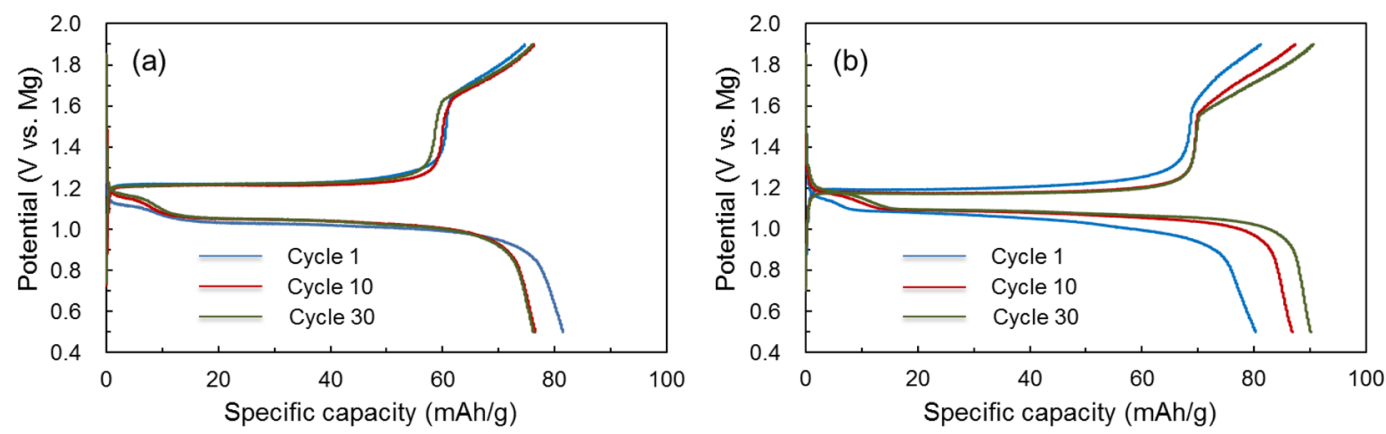

Figure 9. Galvanostatic charge-discharge profiles of a coin-type cell with $\mathrm{Mo}_{6} \mathrm{~S}_{8}$ Chevrel phase cathode and AZ31 anode at $\mathrm{C} / 50$-rate (based on the mass of $\mathrm{Mo}_{6} \mathrm{~S}_{8}$ ) with the $\mathrm{B}(\mathrm{OMgCl})_{3}$-based electrolyte in (a) triglyme and (b) triglyme-THF.

with a $\mathrm{B}(\mathrm{OMgCl})_{3}$-based electrolyte up to $1.9 \mathrm{~V}$ vs. $\mathrm{Mg}$. The $\mathrm{B}(\mathrm{OMgCl})_{3}-\mathrm{AlCl}_{3} /$ triglyme electrolyte can be used in higher-voltage cathodes (up to $2.1 \mathrm{~V}$ vs. $\mathrm{Mg}$ ) ${ }^{54}$, implying that this electrolyte is useful for the development of novel cathode materials.

\section{Conclusions}

In this study, three novel electrolytes based on $\mathrm{Ph}_{3} \mathrm{COMgCl}, \mathrm{Ph}_{3} \mathrm{SiOMgCl}$, and $\mathrm{B}(\mathrm{OMgCl})_{3}$ were successfully prepared, and the electrochemical properties were investigated. The $\mathrm{Ph}_{3} \mathrm{COMgCl}$-based electrolyte showed higher anodic stability than the $\mathrm{Ph}_{3} \mathrm{SiOMgCl}$-based electrolyte, and the $\mathrm{B}(\mathrm{OMgCl})_{3}$-based electrolyte showed the highest anodic stability among the three electrolytes. Moreover, the latter was chemically stable, which was ascribed to the Lewis acidic character of boron in $\mathrm{B}(\mathrm{OMgCl})_{3}$. Analyses of $\mathrm{B}(\mathrm{OMgCl})_{3}$ showed that the Grignard reagent mainly reacted with $\mathrm{B}(\mathrm{OH})_{3}$ as a Brønsted acid and revealed that the $\mathrm{BO}_{3}{ }^{3-}$ unit derived from $\mathrm{B}(\mathrm{OH})_{3}$ remained in $\mathrm{B}(\mathrm{OMgCl})_{3}$. In addition, the electrochemically positive $\mathrm{Mg}^{2+}$ ion is the main species present. Charge-discharge measurements performed for the $\mathrm{B}(\mathrm{OMgCl})_{3}$-based electrolyte, a $\mathrm{Mo}_{6} \mathrm{~S}_{8}$ Chevrel phase cathode, and an AZ31 anode were indicative of a reversible charge-discharge capacity, suggesting that hardly any side reaction occurred inside SUS cells with the $\mathrm{B}(\mathrm{OMgCl})_{3}$-based electrolyte at $1.9 \mathrm{~V}$. Although the $\mathrm{B}(\mathrm{OMgCl})_{3}$-based electrolyte did not show high Coulombic efficiency, it showed high anodic stability and can therefore be used in the development of positive electrodes for magnesium batteries.

Received: 19 February 2020; Accepted: 9 April 2020;

Published online: 30 April 2020

\section{References}

1. Muldoon, J., Bucur, C. B. \& Gregory, T. Quest for Nonaqueous Multivalent Secondary Batteries: Magnesium and Beyond. Chem. Rev. 114, 11683-11720, https://doi.org/10.1021/cr500049y (2014).

2. Song, J., Sahadeo, E., Noked, M. \& Lee, S. B. Mapping the Challenges of Magnesium Battery. J. Phys. Chem. Lett. 7, 1736-1749, https://doi.org/10.1021/acs.jpclett.6b00384 (2016).

3. Saha, P. et al. Rechargeable magnesium battery: Current status and key challenges for the future. Prog. Mater Sci. 66, 1-86, https:// doi.org/10.1016/j.pmatsci.2014.04.001 (2014).

4. Aurbach, D. et al. Prototype systems for rechargeable magnesium batteries. Nature 407, 724-727, https://doi.org/10.1038/35037553 (2000).

5. Pour, N., Gofer, Y., Major, D. T. \& Aurbach, D. Structural Analysis of Electrolyte Solutions for Rechargeable Mg Batteries by Stereoscopic Means and DFT Calculations. J. Am. Chem. Soc. 133, 6270-6278, https://doi.org/10.1021/ja1098512 (2011).

6. Mizrahi, O. et al. Electrolyte Solutions with a Wide Electrochemical Window for Rechargeable Magnesium Batteries. J. Electrochem. Soc. 155, A103-A109, https://doi.org/10.1149/1.2806175 (2008).

7. Aurbach, D., Weissman, I., Gofer, Y. \& Levi, E. Nonaqueous magnesium electrochemistry and its application in secondary batteries. The Chemical Record 3, 61-73, https://doi.org/10.1002/tcr.10051 (2003).

8. Wall, C., Zhao-Karger, Z. \& Fichtner, M. Corrosion Resistance of Current Collector Materials in Bisamide Based Electrolyte for Magnesium Batteries. ECS Electrochemistry Letters 4, C8-C10, https://doi.org/10.1149/2.0111501eel (2015).

9. Kim, H. S. et al. Structure and compatibility of a magnesium electrolyte with a sulphur cathode. Nature Commun. 2, 427, https://doi. org/10.1038/ncomms1435 (2011).

10. Nelson, E. G., Kampf, J. W. \& Bartlett, B. M. Enhanced oxidative stability of non-Grignard magnesium electrolytes through ligand modification. Chem. Commun. 50, 5193-5195, https://doi.org/10.1039/C3CC47277A (2014).

11. Wang, F.-f., Guo, Y.-s., Yang, J., Nuli, Y. \& Hirano, S.-i. A novel electrolyte system without a Grignard reagent for rechargeable magnesium batteries. Chem. Commun. 48, 10763-10765, https://doi.org/10.1039/C2CC35857C (2012).

12. Nist-Lund, C. A., Herb, J. T. \& Arnold, C. B. Improving halide-containing magnesium-ion electrolyte performance via sterically hindered alkoxide ligands. J. Power Sources 362, 308-314, https://doi.org/10.1016/j.jpowsour.2017.07.045 (2017).

13. Herb, J. T., Nist-Lund, C. A. \& Arnold, C. B. A fluorinated dialkoxide-based magnesium-ion electrolyte. J. Mater. Chem. A 5, 7801-7805, https://doi.org/10.1039/C7TA01578J (2017).

14. Herb, J. T., Nist-Lund, C., Schwartz, J. \& Arnold, C. B. Structural Effects of Magnesium Dialkoxides as Precursors for MagnesiumIon Electrolytes. ECS Electrochemistry Letters 4, A49-A52, https://doi.org/10.1149/2.0031506eel (2015).

15. Liao, C. et al. Highly soluble alkoxide magnesium salts for rechargeable magnesium batteries. J. Mater. Chem. A 2, 581-584, https:// doi.org/10.1039/c3ta13691d (2014)

16. Liu, T. B. et al. A facile approach using $\mathrm{MgCl} 2$ to formulate high performance $\mathrm{Mg} 2+$ electrolytes for rechargeable $\mathrm{Mg}$ batteries. J. Mater. Chem. A 2, 3430-3438, https://doi.org/10.1039/c3ta14825d (2014). 
17. Doe, R. E. et al. Novel, electrolyte solutions comprising fully inorganic salts with high anodic stability for rechargeable magnesium batteries. Chem. Commun. 50, 243-245, https://doi.org/10.1039/c3cc47896c (2014).

18. Orikasa, Y. et al. High energy density rechargeable magnesium battery using earth-abundant and non-toxic elements. Sci. Rep. 4 , 5622, https://doi.org/10.1038/Srep05622 (2014).

19. Ha, S.-Y. et al. Magnesium(II) Bis(trifluoromethane sulfonyl) Imide-Based Electrolytes with Wide Electrochemical Windows for Rechargeable Magnesium Batteries. ACS Appl. Mater. Interfaces 6, 4063-4073, https://doi.org/10.1021/am405619v (2014).

20. Fukutsuka, T. et al. New Magnesium-ion Conductive Electrolyte Solution Based on Triglyme for Reversible Magnesium Metal Deposition and Dissolution at Ambient Temperature. Chem. Lett. 43, 1788-1790, https://doi.org/10.1246/cl.140704 (2014).

21. Carter, T. J. et al. Boron Clusters as Highly Stable Magnesium-Battery Electrolytes. Angew. Chem. Int. Ed. 53, 3173-3177, https://doi. org/10.1002/anie.201310317 (2014).

22. McArthur, S. G., Geng, L., Guo, J. \& Lavallo, V. Cation reduction and comproportionation as novel strategies to produce high voltage, halide free, carborane based electrolytes for rechargeable Mg batteries. Inorganic Chemistry Frontiers 2, 1101-1104, https:// doi.org/10.1039/C5QI00171D (2015).

23. McArthur, S. G., Jay, R., Geng, L., Guo, J. \& Lavallo, V. Below the 12-vertex: 10-vertex carborane anions as non-corrosive, halide free, electrolytes for rechargeable Mg batteries. Chem. Commun. 53, 4453-4456, https://doi.org/10.1039/C7CC01570D (2017).

24. Jay, R. et al. Comparative Study of $\mathrm{Mg}(\mathrm{CB} 11 \mathrm{H} 12) 2$ and $\mathrm{Mg}(\mathrm{TFSI}) 2$ at the Magnesium/Electrolyte Interface. ACS Appl. Mater. Interfaces 11, 11414-11420, https://doi.org/10.1021/acsami.9b00037 (2019).

25. Peled, E. \& Straze, H. The Kinetics of the Magnesium Electrode in Thionyl Chloride Solutions. J. Electrochem. Soc. 124, 1030-1035, https://doi.org/10.1149/1.2133474 (1977)

26. See, K. A. et al. The Interplay of $\mathrm{Al}$ and $\mathrm{Mg}$ Speciation in Advanced Mg Battery Electrolyte Solutions. J. Am. Chem. Soc. 138, 328-337, https://doi.org/10.1021/jacs.5b10987 (2016).

27. Barile, C. J., Barile, E. C., Zavadil, K. R., Nuzzo, R. G. \& Gewirth, A. A. Electrolytic Conditioning of a Magnesium Aluminum Chloride Complex for Reversible Magnesium Deposition. J. Phys. Chem. C 118, 27623-27630, https://doi.org/10.1021/jp506951b (2014).

28. Shterenberg, I. et al. Evaluation of (CF3SO2)2N- (TFSI) Based Electrolyte Solutions for Mg Batteries. J. Electrochem. Soc. 162, A7118-A7128, https://doi.org/10.1149/2.0161513jes (2015).

29. Shterenberg, I., Salama, M., Gofer, Y. \& Aurbach, D. Hexafluorophosphate-Based Solutions for Mg Batteries and the Importance of Chlorides. Langmuir 33, 9472-9478, https://doi.org/10.1021/acs.langmuir.7b01609 (2017).

30. Mohtadi, R. \& Mizuno, F. Magnesium batteries: Current state of the art, issues and future perspectives. Beilstein J Nanotechnol 5, 1291-1311, https://doi.org/10.3762/bjnano.5.143 (2014).

31. Nakanishi, K. et al. Novel spectro-electrochemical cell for in situ/operando observation of common composite electrode with liquid electrolyte by X-ray absorption spectroscopy in the tender X-ray region. Rev. Sci. Instrum. 85, 084103, https://doi. org $/ 10.1063 / 1.4891036(2014)$.

32. Prabakar, S. J. R., Park, C., Ikhe, A. B., Sohn, K.-S. \& Pyo, M. Simultaneous Suppression of Metal Corrosion and Electrolyte Decomposition by Graphene Oxide Protective Coating in Magnesium-Ion Batteries: Toward a 4-V-Wide Potential Window. ACS Appl. Mater. Interfaces 9, 43767-43773, https://doi.org/10.1021/acsami.7b16103 (2017).

33. Guo, Y.-s et al. Boron-based electrolyte solutions with wide electrochemical windows for rechargeable magnesium batteries. Energy Environ. Sci. 5, 9100-9106, https://doi.org/10.1039/C2EE22509C (2012).

34. Aurbach, D. et al. Electrolyte Solutions for Rechargeable Magnesium Batteries Based on Organomagnesium Chloroaluminate Complexes. J. Electrochem. Soc. 149, A115-A121, https://doi.org/10.1149/1.1429925 (2002).

35. Jache, B., Binder, J. O., Abe, T. \& Adelhelm, P. A comparative study on the impact of different glymes and their derivatives as electrolyte solvents for graphite co-intercalation electrodes in lithium-ion and sodium-ion batteries. Phys. Chem. Chem. Phys. 18, 14299-14316, https://doi.org/10.1039/C6CP00651E (2016).

36. Das, B., Roy, M. N. \& Hazra, D. K. Densities and viscosities of the binary aqueous mixtures of tetrahydrofuran and 1,2-dimethoxyethane at 298, 308 and 318 K. Indian J. Chem. Technol. 1, 93-97 (1994).

37. Seguin, T. J., Hahn, N. T., Zavadil, K. R. \& Persson, K. A. Elucidating Non-aqueous Solvent Stability and Associated Decomposition Mechanisms for Mg Energy Storage Applications From First-Principles. Frontiers in Chemistry 7, https://doi.org/10.3389/ fchem.2019.00175 (2019).

38. Kitada, A. et al. Room Temperature Magnesium Electrodeposition from Glyme-Coordinated Ammonium Amide Electrolytes. J. Electrochem. Soc. 162, D389-D396, https://doi.org/10.1149/2.0731508jes (2015).

39. Esbenshade, J. L. et al. Improving Electrodeposition of Mg through an Open Circuit Potential Hold. J. Phys. Chem. C 119, 23366-23372, https://doi.org/10.1021/acs.jpcc.5b07825 (2015).

40. Gummow, R. J. \& He, Y. Morphology and Preferred Orientation of Pulse Electrodeposited Magnesium. J. Electrochem. Soc. 157, E45-E49, https://doi.org/10.1149/1.3298883 (2010).

41. Kim, I. T. et al. Characteristics of tetrahydrofuran-based electrolytes with magnesium alkoxide additives for rechargeable magnesium batteries. J. Power Sources 323, 51-56, https://doi.org/10.1016/j.jpowsour.2016.05.045 (2016).

42. Aurbach, D., Turgeman, R., Chusid, O. \& Gofer, Y. Spectroelectrochemical studies of magnesium deposition by in situ FTIR spectroscopy. Electrochem. Commun. 3, 252-261, https://doi.org/10.1016/S1388-2481(01)00148-5 (2001).

43. Fulmer, G. R. et al. NMR Chemical Shifts of Trace Impurities: Common Laboratory Solvents, Organics, and Gases in Deuterated Solvents Relevant to the Organometallic Chemist. Organometallics 29, 2176-2179, https://doi.org/10.1021/om100106e (2010).

44. Dewar, M. J. S. \& Jones, R. New heteroaromatic compounds. XXV. Studies of salt formation in boron oxyacids by boron-11 nuclear magnetic resonance. J. Am. Chem. Soc. 89, 2408-2410, https://doi.org/10.1021/ja00986a029 (1967).

45. See, K. A., Liu, Y.-M., Ha, Y., Barile, C. J. \& Gewirth, A. A. Effect of Concentration on the Electrochemistry and Speciation of the Magnesium Aluminum Chloride Complex Electrolyte Solution. ACS Appl. Mater. Interfaces 9, 35729-35739, https://doi. org/10.1021/acsami.7b08088 (2017).

46. Merrill, L. C. \& Schaefer, J. L. Electrochemical Properties and Speciation in Mg(HMDS)2-Based Electrolytes for Magnesium Batteries as a Function of Ethereal Solvent Type and Temperature. Langmuir 33, 9426-9433, https://doi.org/10.1021/acs. langmuir.7b01111 (2017).

47. Kitada, A., Nakamura, K., Fukami, K. \& Murase, K. Electrochemically active species in aluminum electrodeposition baths of $\mathrm{AlCl}_{3} /$ glyme solutions. Electrochim. Acta 211, 561-567, https://doi.org/10.1016/j.electacta.2016.05.063 (2016).

48. Nakayama, Y. et al. Complex Structures and Electrochemical Properties of Magnesium Electrolytes. J. Electrochem. Soc. 155, A754-A759, https://doi.org/10.1149/1.2956022 (2008).

49. Benmayza, A. et al. Effect of Electrolytic Properties of a Magnesium Organohaloaluminate Electrolyte on Magnesium Deposition. J. Phys. Chem. C 117, 26881-26888, https://doi.org/10.1021/jp4077068 (2013).

50. Hattori, M. et al. Role of Coordination Structure of Magnesium Ions on Charge and Discharge Behavior of Magnesium Alloy Electrode. J. Phys. Chem. C 122, 25204-25210, https://doi.org/10.1021/acs.jpcc.8b08558 (2018).

51. Bieker, G. et al. The Power of Stoichiometry: Conditioning and Speciation of $\mathrm{MgCl} 2 / \mathrm{AlCl} 3$ in Tetraethylene Glycol Dimethyl EtherBased Electrolytes. ACS Appl. Mater. Interfaces 11, 24057-24066, https://doi.org/10.1021/acsami.9b05307 (2019).

52. Nakayama, Y. et al. Sulfone-based electrolytes for aluminium rechargeable batteries. Phys. Chem. Chem. Phys. 17, 5758-5766, https://doi.org/10.1039/C4CP02183E (2015). 
53. Stafford, G. R., Tsuda, T. \& Hussey, C. L. The Structure of Electrodeposited Aluminum Alloys from Chloroaluminate Ionic Liquids: Let's Not Ignore the Temperature. ECS Transactions 64, 535-547, https://doi.org/10.1149/06404.0535ecst (2014).

54. Sato, K., Mizuta, H. \& Okamoto, K. Positive Electrode Active Material For Magnesium Batteries. WO2020/027079A1 (2020).

\section{Acknowledgements}

This work was financially supported by Kansai Research Foundation for technology promotion.

\section{Author contributions}

K.S., K.O. and Y.O. designed the research. K.S. performed the electrochemical measurements and DFT calculation and analyzed FTIR, NMR data. G.M. and T.K. prepared the electrolytes. T.Y., K.N. and T.O. performed $\mathrm{X}$-ray absorption spectroscopy measurements. Y.O. analyzed X-ray diffraction and X-ray absorption spectra. All authors discussed and commented on the manuscript.

\section{Competing interests}

The authors declare no competing interests.

\section{Additional information}

Supplementary information is available for this paper at https://doi.org/10.1038/s41598-020-64085-2.

Correspondence and requests for materials should be addressed to Y.O.

Reprints and permissions information is available at www.nature.com/reprints.

Publisher's note Springer Nature remains neutral with regard to jurisdictional claims in published maps and institutional affiliations.

(c) (i) Open Access This article is licensed under a Creative Commons Attribution 4.0 International License, which permits use, sharing, adaptation, distribution and reproduction in any medium or format, as long as you give appropriate credit to the original author(s) and the source, provide a link to the Creative Commons license, and indicate if changes were made. The images or other third party material in this article are included in the article's Creative Commons license, unless indicated otherwise in a credit line to the material. If material is not included in the article's Creative Commons license and your intended use is not permitted by statutory regulation or exceeds the permitted use, you will need to obtain permission directly from the copyright holder. To view a copy of this license, visit http://creativecommons.org/licenses/by/4.0/.

(C) The Author(s) 2020 